\title{
Analisis Artikulasi Laporan Keuangan Pemerintah Daerah
}

\author{
M. Ahlal Firdaus ${ }^{1}$, Irwan Taufiq Ritonga ${ }^{1}$ \\ ${ }^{1)}$ Fakultas Ekonomika dan Bisnis, Universitas Gadjah Mada
}

\begin{abstract}
This research aims to analyse the articulation of sixty six unqualified opinion of local government financial statements (LKPD) for fiscal year year 2014 in Java and Bali. This research also identify types of inarticulatory when a LKPD is in inarticulate condition. This research utilizes descriptive qualitative approach and uses documentation technique for data collection. The analysis is employed by comparing the fact on the face (lembar muka) of LKPD with the criteria in accordance to accounting equation and Government Accounting Standard (SAP). Identification of inarticulatory is performed using documentation technique through a deep information extracting from audited result report BPK RI. The results of articulation assessment show that most of LKPD (89,39\%) are not articulate, on average level of artikculation is $82,67 \%$. Furthermores, identification results of inarticulatory types show there are twelve types of inarticulatory with 97 cases on cash toward accrual based LKPD and 10 types of inarticulatory with 24 cases on accrual based LKPD.
\end{abstract}

Abstrak: Penelitian ini bertujuan untuk menganalisis artikulasi 66 (enam puluh enam) laporan keuangan pemerintah daerah (LKPD) tahun 2014 se-Jawa dan Bali yang beropini wajar tanpa pengecualian (WTP). Penelitian ini juga bertujuan untuk mengidentifikasi tipe ketidakartikulasian apabila LKPD mengalami kondisi tidak artikulasi. Penelitian ini menggunakan pendekatan kualitatif deskriptif dan menggunakan teknik dokumentasi untuk pengumpulan data. Analisis dilakukan dengan membandingkan fakta dalam lembar muka LKPD dengan kriteria yang didasarkan pada persamaan akuntansi dan Standar Akuntansi Pemerintahan (SAP). Identifikasi tipe ketidakartikulasian dilakukan dengan teknik dokumentasi melalui penggalian informasi lebih mendalam terhadap laporan hasil audit BPK RI. Hasil penilaian artikulasi menunjukkan sebagian besar LKPD (89,39\%) tidak berartikulasi, secara rata-rata tingkat artikulasi LKPD sebesar 82,67\%. Selanjutnya, hasil identifikasi tipe ketidakartikulasian, terdapat 12 tipe ketidakartikulasian dengan 97 kejadian pada LKPD berbasis kas menuju akrual dan 10 tipe ketidakartikulasian dengan 24 kejadian pada LKPD berbasis akrual.

Kata kunci: artikulasi, laporan keuangan pemerintah daerah, pelaporan berbasis akrual

\footnotetext{
${ }^{1}$ Corresponding author's email: hafidz2ahlal@gmail.com
} 


\section{Pendahuluan}

Laporan Keuangan Pemerintah Daerah (LKPD) sebagai pertanggungjawaban kepala daerah merupakan amanat Undang-Undang Nomor 17 Tahun 2003 yang harus disusun mengacu pada Standar Akuntansi Pemerintahan (SAP). LKPD sebagai informasi akuntansi diharapkan dapat memberikan manfaat sebagaimana diungkapkan oleh Given (1996) bahwa informasi akuntansi harus bermanfaat dan kewajaran untuk semua pihak dan setiap saat harus menjadi dasar dalam akumulasi dan penyajian informasi akuntansi.

Guna menjamin LKPD yang bermanfaat, SAP menentukan karakteristik kualitatif laporan keuangan dalam Kerangka Konseptual (KK) Paragraf 32 yaitu relevan, andal, dapat dibandingkan, dan dapat dipahami. Penelitian ini akan mendeskripsikan sejauh mana karakteristik andal telah terpenuhi dalam penyusunan LKPD yang ditunjukkan dengan capaian tingkat artikulasi LKPD.

Pada tahun 2015 BPK RI telah melakukan audit atas LKPD tahun 2014 sebanyak 504 LKPD (BPK RI 2015). Hasil audit memperlihatkan bahwa LKPD tahun 2014 mengalami kenaikan opini yang signifikan. Hal tersebut ditunjukkan dengan adanya kenaikan opini pada 130 LKPD. Kenaikan opini hendaknya menandakan LKPD yang semakin berkualitas. Pada tahun 2015 terdapat 251 (49,80\%) LKPD dengan opini WTP. Namun, apakah LKPD yang beropini WTP sudah menjamin terbebas dari kesalahan artikulasi? Tentunya ini memerlukan penelitian yang mendalam.

Penelitian artikulasi laporan keuangan telah dilakukan pada sektor privat seperti penelitian Bahnson, Miller, \& Budge (1996) yang meneliti sebanyak 9.757 set laporan keuangan tahun 1987 sampai dengan 1990 di Amerika Serikat, kemudian Kinnunen \&
Koskella (1999) meneliti perusahaan yang terdaftar di bursa efek Finlandia sejak tahun 1995 sampai dengan 1997. Kedua penelitian tersebut menemukan adanya indikasi laporan arus kas yang tidak selalu berartikulasi dengan laporan laba rugi dan neraca. Penelitian yang mengkhususkan pada penilaian artikulasi laporan keuangan di Indonesia baik sektor privat maupun publik, sejauh pengetahuan terbaik peneliti, belum pernah dilakukan. Guna memeroleh deskripsi tingkat artikulasi LKPD dan mengidentifikasi tipe ketidakartikulasian apabila LKPD tidak berartikulasi, maka penelitian ini dilakukan.

\section{Kajian Pustaka}

\section{Artikulasi Laporan Keuangan}

Makna artikulasi dalam Kamus Besar Bahasa Indonesia (KBBI) Daring (Pusat Bahasa Departemen Pendidikan Nasional Republik Indonesia 2008) ialah 1 sendi; 2 a sambungan di antara dua bagian, msl tempat melekatnya daun pd ranting; b buku pd batang; 3 a lafal, pengucapan kata; $b$ perubahan rongga dan ruang dl saluran suara untuk menghasilkan bunyi bahasa. Sedangkan kata artikulasi dalam konteks akuntansi sebagaimana disampaikan oleh Suwardjono (2013) adalah sebagai berikut:

artikulasi merupakan turunan atau konsekuensi dari konsep kesatuan usaba. Dengan artikulasi, akan selalu dapat ditunjukkan babwa laba dalam statemen laba-rugi akan sama dengan laba dalam statemen berubahan ekuitas dan jumlah rupiah ekuitas akbir dalam statemen perubaban ekuitas akan sama dengan jumlab rupiab ekuitas dalam neraca.

Artikulasi laporan keuangan terjadi mengingat laporan keuangan disusun dari elemen-elemen laporan keuangan yang merepresentasikan persamaan akuntansi. Suwardjono (2013) menyatakan sistem 
akuntansi diorganisasi atas dasar persamaan akuntansi yang merupakan hubungan fungsional buku besar yang dinyatakan sebagai berikut:

$$
\begin{aligned}
\operatorname{Aset}(\mathrm{A})= & \text { Kewajiban }(\mathrm{K})+\text { Ekuitas }(\mathrm{E})+ \\
& \operatorname{Pendapatan}(\mathrm{P})-\operatorname{Biaya}(\mathrm{B})
\end{aligned}
$$

Artikulasi laporan keuangan dalam konteks persamaan akuntansi digambarkan oleh Suwardjono (2013) seperti dalam Gambar 1 berikut.

Dari gambar 1 dapat diketahui bahwa artikulasi akan terjadi saat jumlah akhir ekuitas pada laporan perubahan ekuitas akan sama dengan jumlah ekuitas pada neraca akhir. Sedangkan jumlah ekuitas akhir dalam laporan perubahan ekuitas diperoleh dari ekuitas pada neraca awal ditambah laba/rugi dalam laporan laba-rugi dan transaksi modal bersih dalam laporan transaksi modal bersih.

Dalam organisasi privat, perusahaan menyiapkan empat jenis laporan keuangan yaitu laporan laba-rugi (income statement), laporan laba ditahan (retained earnings statement), laporan posisi keuangan/ neraca (statement of financial position/balance sheet), dan laporan aliran kas (statement of cash
flows).Weygandt, Kimmel dan Kieso (2013) menyatakan hubungan antarlaporan keuangan tidak menggunakan kata artikulasi melainkan menggunakan kata saling berhubungan (interrelated). Keempat jenis laporan keuangan tersebut saling berhubungan diilustrasikan sebagai berikut pada Gambar 2.

\section{Artikulasi Laporan Keuangan Pemerintah Daerah}

Artikulasi LKPD bisa disebut sebagai hubungan/kesesuaian/pertemuan antarlaporan keuangan pemerintah daerah. Ritonga (2010) menggunakan kata keterkaitan pos-pos antarlaporan keuangan untuk mengatakan bahwa antarlaporan keuangan memiliki keterkaitan (berartikulasi). Mahmudi (2007) menyebutnya sebagai rekonsiliasi antara laporan keuangan, kemudian Ratmono dan Sholihin (2015) menggunakan kata hubungan untuk menjelaskan adanya hubungan antarjenis laporan keuangan. Dengan demikian, artikulasi LKPD bisa diartikan sebagai kondisi saling berhubungan atau keterkaitan antarkomponen dalam suatu LKPD maupun antarpos-pos/unsur dalam suatu komponen LKPD.

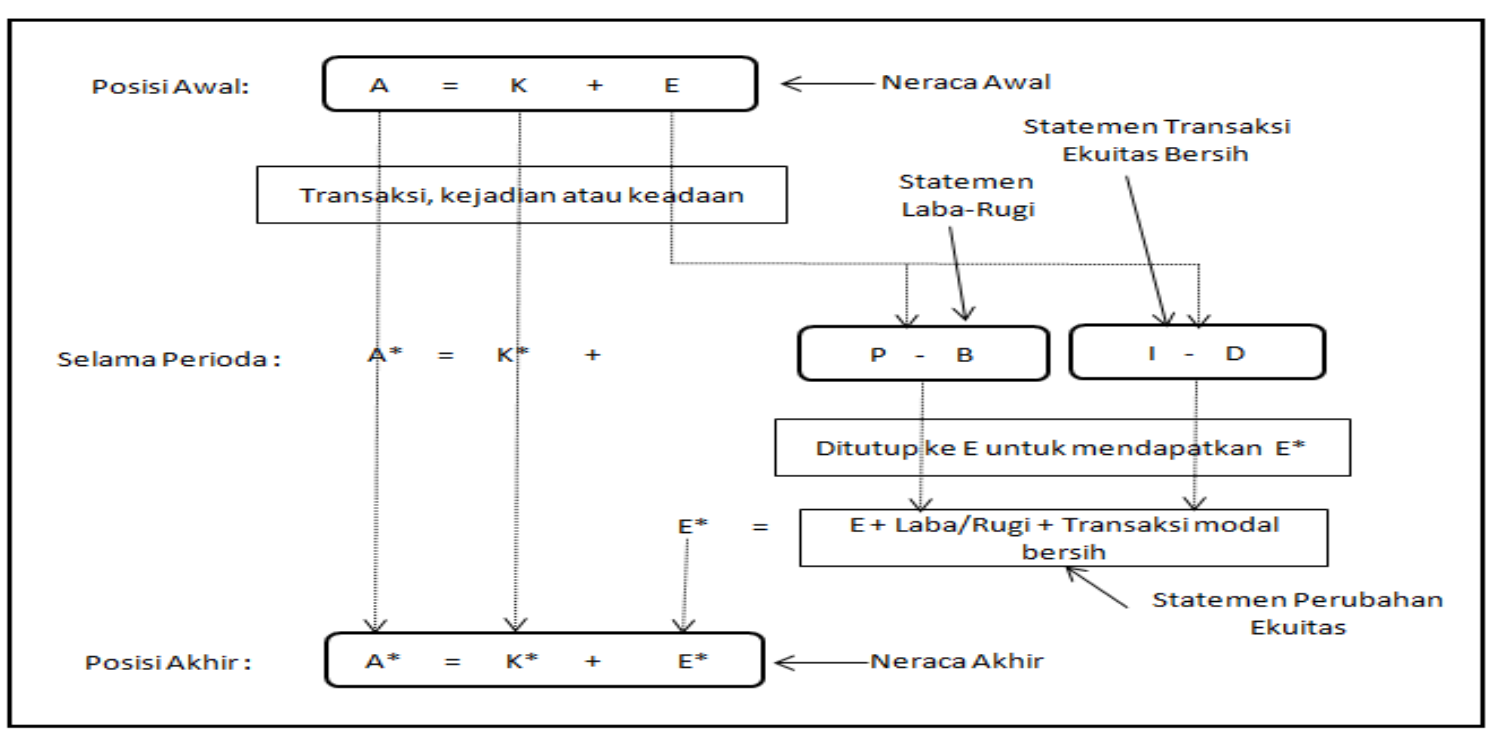

Gambar 1. Artikulasi Statemen Keuangan (Suwardjono 2013) 


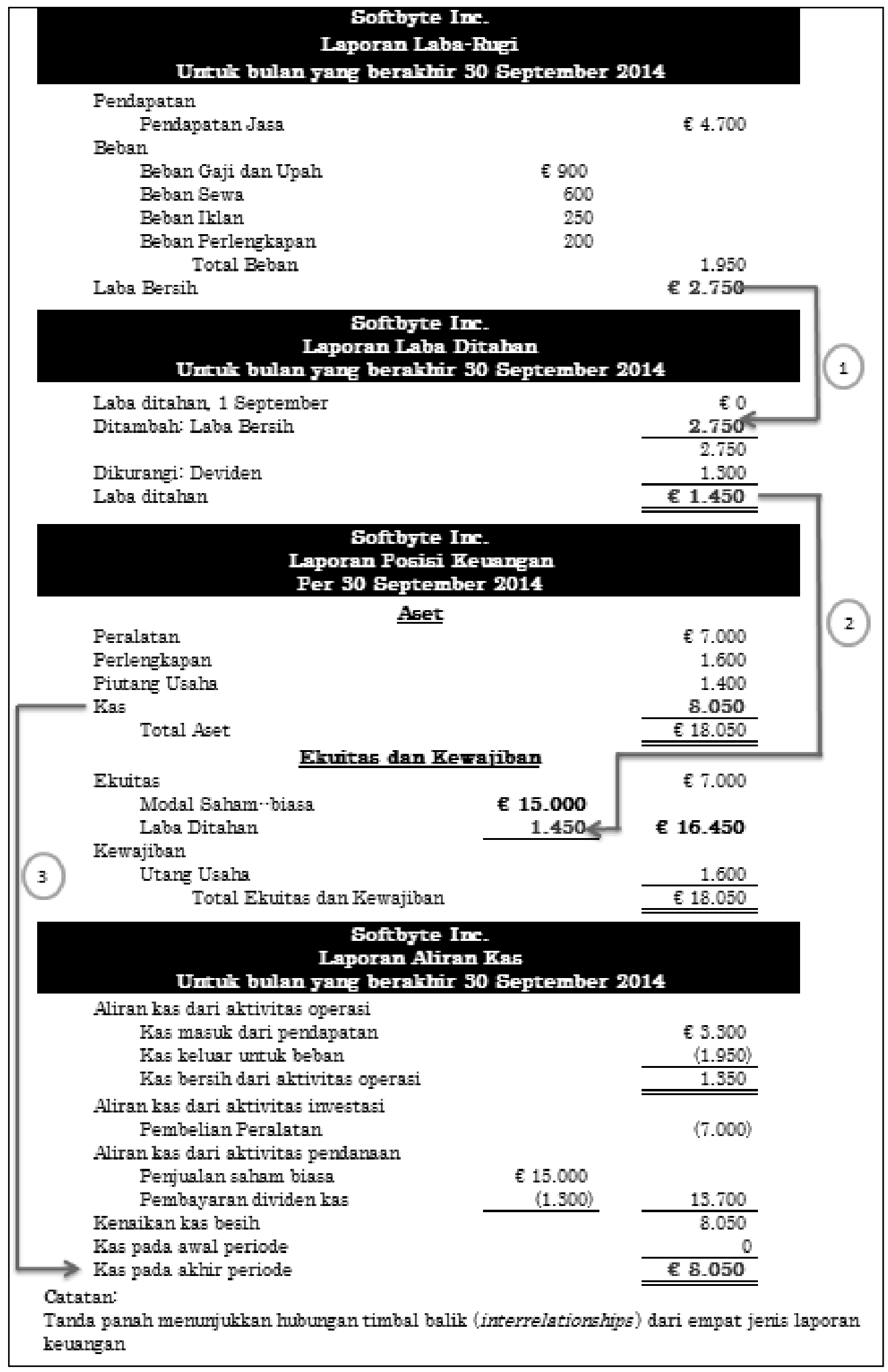

Gambar 2. Ilustrasi Hubungan Antarjenis Laporan Keuangan

(Weygandt, Kimmel dan Kieso 2013) 


\section{Komponen dan Pos-pos LKPD}

LKPD terdiri atas komponen LKPD dan setiap komponen LKPD tersusun atas pos-pos LKPD. Komponen dan pos-pos LKPD dibedakan menurut basis akuntansi yang diterapkan. Perbedaan komponen LKPD menurut basis akuntansi yang diterapkan sebagai berikut (Tabel 1).
Pos-pos/unsur dalam satu komponen LKPD ialah bagian yang membentuk suatu komponen LKPD. Pos-pos/unsur dalam LKPD menurut PP No. 24 Tahun 2005 dan PP No. 71 Tahun 2010 sebagai berikut (Tabel 2).

Tabel 1

Komponen LKPD Berdasarkan Basis Akuntansi yang Diterapkan

\begin{tabular}{ll}
\hline Komponen LKPD Berbasis Kas Menuju Akrual & \multicolumn{1}{c}{ Komponen LKPD BerbasisAkrual } \\
\hline Laporan Realisasi Anggaran (LRA) & Laporan Realisasi Anggaran (LRA) \\
Neraca & Laporan Perubahan Saldo Aanggaran Lebih \\
& (Laporan Perubahan SAL) \\
Laporan Arus Kas (LAK) & Laporan Operasional (LO) \\
Catatan atas Laporan Keuangan (CaLK) & Neraca \\
& Laporan Arus Kas (LAK) \\
& Laporan Perubahan Ekuitas (LPE) \\
& Catatan atas Laporan Keuangan (CaLK) \\
\hline
\end{tabular}

Tabel 2

Tabel Pos-pos/Unsur LKPD

\begin{tabular}{|c|c|}
\hline PP No. 24 Tahun 2005 & PP No. 71 Tahun 2010 \\
\hline Pos-pos LRA sebagai berikut: & Pos-pos LRA sebagai berikut: \\
\hline Pendapatan, belanja, transfer, dan pembiayaan & Pendapatan, belanja, transfer, dan pembiayaan \\
\hline Pos-pos LPSAL, tidak dijelaskan. & $\begin{array}{l}\text { Pos-pos Laporan Perubahan SAL sebagai berikut: } \\
\text { SAL awal, Penggunaan Saldo Anggaran Lebih, Sisa } \\
\text { Lebih/Kurang Pembiayaan Anggaran tahun berjalan, } \\
\text { Koreksi Kesalahan Pembukuan tahun Sebelumnya, } \\
\text { Lain-lain, SAL Akhir. }\end{array}$ \\
\hline $\begin{array}{l}\text { Pos-pos Neraca meliputi unsur-unsur aset, } \\
\text { kewajiban, dan ekuitas, selanjutnya masing- } \\
\text { masing unsur diklasifikasikan lebih lanjut ke } \\
\text { dalam unsur yang lebih rinci. }\end{array}$ & $\begin{array}{l}\text { Pos-pos neraca meliputi unsur-unsur yang tidak } \\
\text { berbeda dengan PP lama. }\end{array}$ \\
\hline LO, unsur-unsur LO tidak dijelaskan. & $\begin{array}{l}\text { LO meliputi unsur-unsur: pendapatan-LO, beban, } \\
\text { transfer, dan pos luar biasa. }\end{array}$ \\
\hline $\begin{array}{l}\text { LAK mencakup unsur-unsur penerimaan kas } \\
\text { dan pengeluaran kas. }\end{array}$ & $\begin{array}{l}\text { LAK mencakup unsur-unsur yang tidak berbeda } \\
\text { dengan PP lama. }\end{array}$ \\
\hline LPE, unsur-unsur LPE tidak dijelaskan. & $\begin{array}{l}\text { LPE mencakup unsur-unsur: ekuitas awal, } \\
\text { Surplus/defisit-LO pada periode bersangkutan, koreksi- } \\
\text { koreksi yang langsung menambah/mengurangi ekuitas, } \\
\text { dan ekuitas akhir. }\end{array}$ \\
\hline
\end{tabular}




\section{Metoda Penelitian}

\section{Objek dan Sampel Penelitian}

Penentuan objek penelitian artikulasi LKPD menggunakan teknik purposive sampling agar diperoleh sampel yang memenuhi tujuan tertentu yang menjadi pertimbangan peneliti (Sugiyono 2015). Penentuan objek berupa penelitian LKPD Tahun 2014 se-Jawa dan Bali yang beropini WTP dengan pertimbangan sebagai berikut:

a. LKPD audited dan beropini WTP, kriteria ini dimaksudkan agar LKPD yang diteliti telah memenuhi unsur validitas dan ketepatan sesuai dengan SAP (Jusup 2010). LKPD audited secara umum merupakan LKPD yang dapat diandalkan karena telah melalui audit yang independen (Jusup 2010). Opini WTP adalah opini tertinggi yang menjadi jaminan keandalan suatu LKPD.

b. LKPD tahun 2014, kriteria tahun 2014 ditetapkan mengingat LKPD tahun 2014 adalah LKPD termutakhir yang telah diaudit oleh BPK RI pada saat penelitian ini dilakukan.

c. LKPD se-Jawa dan Bali, kriteria se-Jawa dan Bali dikarenakan persepsi umum yang menyatakan bahwa kualitas SDM dan sarana-prasarana penunjang pengelolaan keuangan dan pengauditan oleh BPK RI di Jawa dan Bali telah baik dan mirip sehingga dapat diperbandingkan.

\section{Pendekatan dan Strategi Penelitian}

LKPD Tahun 2014 se-Jawa dan Bali adalah sebanyak 129 LKPD, tetapi yang memenuhi kriteria WTP adalah sebanyak 66 LKPD (BPK RI 2015). Dari 66 LKPD beropini WTP, sebanyak 51 LKPD menerapkan basis kas menuju akrual dan 5 LKPD menerapkan basis akrual.
Pendekatan penelitian ini menggunakan pendekatan kualitatif deskriptif. Peneliti ingin memahami lebih mendalam mengenai informasi akuntansi dalam LKPD yang dipandu oleh persamaan akuntansi bahwa laporan keuangan seharusnya berartikulasi. Cresswell (2014) menyatakan bahwa penelitian kualitatif merupakan pendekatan untuk mengeksplorasi dan memahami makna oleh sejumlah individu atau sekelompok orang dianggap berasal dari masalah sosial atau kemanusiaan. Sugiyono (2015) menyatakan bahwa metode penelitian kualitatif diterapkan/digunakan untuk meneliti objek dalam kondisi alamiah; peneliti sebagai instrumen kunci; pengambilan sampel dengan cara purposive dan snowball.

Strategi penelitian yang digunakan adalah penelitian deskriptif. Peneliti mendeskriptifkan hasil analisis artikulasi LKPD. Peneliti kemudian menjelaskan secara sistematis faktafakta yang ditemukan. Peneliti menggunakan pengalamannya dan juga pengalaman para pihak yang terkait dengan penyusunan dan penyajian LKPD (Soewadji 2012).

Peneliti sebagai instrumen utama (Sugiyono, 2015) dalam penelitian ini mengumpulkan data sekunder menggunakan teknik dokumentasi dan melakukan penggalian secara mendalam atas data sekunder tersebut. Peneliti menganalisis lembar muka (on the face) LKPD.

\section{Teknik Analisis}

Penelitian ini menggunakan teknik deskriptif persentase. Ritonga (2010) menyatakan bahwa teknik deskriptif persentase merupakan teknik untuk menghitung tingkat kesesuaian dengan membuat persentase dari data yang ada, kemudian dideskripsikan. Penghitungan dilakukan seperti dalam formula berikut: 
Total nilai

$\begin{gathered}\text { Tingkat } \\ \text { kesesuaian }\end{gathered}=\frac{\text { yang diperoleh }}{\text { Total kriteria }} \times 100 \%$

Langkah-langkah dalam melakukan teknik deksriptif persentase untuk menentukan tingkat kesesuaian artikulasi LKPD sebagai berikut.

a. Menentukan kriteria artikulasi LKPD sesuai persamaan akuntansi dan SAP.

b. Mencari fakta artikulasi LKPD dalam lembar muka LKPD.

c. Memberikan nilai/skor, yaitu skor 1 jika sesuai dengan kriteria dan skor 0 jika fakta tidak sesuai dengan kriteria.

d. Menjumlahkan total skor yang diperoleh masing-masing LKPD.

e. Menghitung rata-rata persentase tingkat artikulasi LKPD.

f. Memberikan deskripsi dan interpretasi skor persentase tingkat artikulasi LKPD yang diperoleh.

\section{Uji Validitas dan Reliabilitas}

Uji validitas dalam penelitian ini dilakukan dengan meningkatkan ketekunan, analisis kasus negatif, menyusun deskripsi yang kaya dan padat tentang hasil penelitian (Sugiyono 2015). Uji reliabilitas/keandalan dalam penelitian ini dilakukan dengan pengujian dependability yang dilakukan dengan melakukan pemeriksaan terhadap keseluruhan proses penelitian.

\section{Hasil Penelitian dan Pembahasan}

\author{
Hasil Analisis Artikulasi LKPD
}

Analisis terbagi dalam dua kelompok yaitu analisis untuk 61 LKPD berbasis kas menuju akrual (cash toward accrual) dan analisis untuk 5 LKPD berbasis akrual. LKPD tahun 2014 menyajikan informasi keuangan komparasi tahun 2014 dan 2013, sehingga analisis meliputi informasi keuangan tahun 2014 dan 2013. Tingkat capaian artikulasi ditunjukkan dalam bentuk persentase (\%) sebagaimana contoh dalam tabel 3 berikut.

Tabel di atas menggambarkan tingkat capaian artikulasi per LKPD berupa nilai ratarata dari empat nilai artikulasi dalam bentuk persentase. Rata-rata diperoleh dari penjumlahan nilai seluruh data dalam suatu kelompok instrumen, kemudian dibagi dengan jumlah instrumen tersebut. Keempat nilai artikulasi dalam suatu kelompok instrumen tersebut yaitu:

1) nilai artikulasi dari instrumen \#A tahun 2014

2) nilai artikulasi dari instrumen $\# B$ tahun 2013

3) nilai artikulasi dari instrumen \#C tahun 2014

4) nilai artikulasi dari instrumen \#D tahun 2013

Tabel 3

Hasil Analisis Artikulasi Suatu LKPD

\begin{tabular}{clcc}
\hline \multirow{2}{*}{ Instrumen } & \multicolumn{2}{c}{ Nama Instrumen Artikulasi } & \multicolumn{2}{c}{ Tahun } \\
\cline { 3 - 4 } & & 2014 & 2013 \\
\hline$\# \mathrm{X}$ & Artikulasi antarpos dalam suatu komponen laporan keuangan & $100 \%$ & $100 \%$ \\
$\# \mathrm{Y}$ & Artikulasi antarkomponen laporan keuangan & $100 \%$ & $100 \%$ \\
\hline & Tingkat capaian artikulasi per LKPD & \multicolumn{2}{c}{$100 \%$} \\
\hline
\end{tabular}


Dampaknya, tingkat capaian artikulasi per LKPD mengikuti formula sebagai berikut:

$$
\bar{X}=
$$

Nilai instrumen $X 2014+$

$\mathrm{X} 2013+\mathrm{Y} 2014+\mathrm{Y} 2013$

4

Dengan asumsi capaian artikulasi pada semua instrumen bernilai 100\%, maka diperoleh tingkat capaian artikulasi per LKPD sebesar $100 \%$. Guna memudahkan pembacaan hasil analisis artikulasi khususnya hasil analisis artikulasi LKPD berbasis kas menuju akrual, peneliti mengelompokkan tingkat capaian artikulasi mengikuti pembagian kelompok sebagai berikut Tabel 4.

Tabel 4

Kelompok Tingkat Capaian Artikulasi LKPD

\begin{tabular}{cc}
\hline Kelompok & Tingkat Capaian Artikulasi \\
\hline 1 & $100 \%$ \\
2 & $75 \%$ s.d. $<100 \%$ \\
3 & $50 \%$ s.d. $<75 \%$ \\
4 & $25 \%$ s.d. $<50 \%$ \\
5 & $0 \%$ s.d. $<25 \%$ \\
\hline
\end{tabular}

Analisis Artikulasi LKPD Berbasis Kas Menuju Akrual

Berdasarkan hasil analisis artikulasi LKPD berbasis kas menuju akrual diperoleh LKPD yang mencapai tingkat artikulasi $100 \%$ yaitu: Pemko Malang, Pemko Banjar, Pemprov Bali, Pemkab Jembrana, Pemkab Tabanan, Pemkab Bantul, dan Pemkab Sleman. Tingkat capaian artikulasi LKPD dari seluruh LKPD se-Jawa dan Bali yang telah dikelompokkan sesuai kelompok tingkat capaian artikulasi sebagai berikut Tabel 5.

Tabel 5 menunjukkan bahwa dari 61 LKPD yang dianalisis, ternyata hanya 7 LKPD atau $11,48 \%$ yang memeroleh tingkat capaian artikulasi $100 \%$. Sebagian besar 54 (88,52\%) LKPD tidak berartikulasi.

Hasil analisis di atas diperoleh dari analisis artikulasi antarpos dan antarkomponen LKPD. Berikut kriteria analisis artikulasi antarpos LKPD berbasis kas menuju akrual (Tabel 6).

Tabel 5

Tingkat Capaian Artikulasi LKPD Berbasis Kas Menuju Akrual

\begin{tabular}{clcccccc}
\hline \multirow{2}{*}{ No. } & \multicolumn{6}{c}{ LKPD } & \multicolumn{5}{c}{ Tingkat Capaian Artikulasi } & \multirow{2}{*}{$\begin{array}{c}\text { Jumlah } \\
\text { Dianalisis }\end{array}$} \\
\cline { 2 - 7 } & $100 \%$ & $75 \%-<100 \%$ & $50 \%-<75 \%$ & $25 \%-<50 \%$ & $0 \%-<25 \%$ & 24 \\
\hline 1 & Se-Jawa Timur & 1 & 15 & 8 & 0 & 0 & 13 \\
2 & Se-Jawa Barat & 1 & 11 & 1 & 0 & 0 & 9 \\
3 & Se-Jawa Tengah & 0 & 4 & 5 & 0 & 0 & 7 \\
4 & Se-Bali & 3 & 4 & 0 & 0 & 0 & 5 \\
5 & Se-DIY & 2 & 3 & 0 & 0 & 0 & 3 \\
6 & Se-Banten & 0 & 1 & 2 & 0 & 0 & 61 \\
\hline & Jumlah LKPD & 7 & 38 & 16 & 0 & 0 & \\
\hline & $\%$ & 11,48 & 62,30 & 26,23 & 0,00 & 0,00 & \\
\hline
\end{tabular}


Analisis Artikulasi Laporan Keuangan Pemerintah Daerah

Tabel 6

Kriteria Artikulasi Antarpos LKPD Berbasis Kas Menuju Akrual (\#X)

\begin{tabular}{rrr}
\hline Uraian & 2014 & 2013 \\
\hline
\end{tabular}

\#A.1 Artikulasi Antarpos di Laporan Realisasi Anggaran (LRA)

\#A.1.1 Jumlah Pendapatan -Jumlah Belanja-Jumlah Transfer =Surplus/Defisit $\quad$ Ya=1; $\quad$ Ya=1;

Tidak $=0$ Tidak $=0$

\#A.1.2 SILPA $=$ Surplus/Defisit + Penerimaan Pembiayaan - Pengeluaran

$\mathrm{Ya}=1 ; \quad \mathrm{Ya}=1 ;$

Pembiayaan

Tidak $=0$ Tidak $=0$

\#A.2 Artikulasi Antarpos di Neraca

\#A.2.1 Jumlah Aset = Jumlah Kewajiban + Jumlah Ekuitas Dana

$\mathrm{Ya}=1 ; \quad \mathrm{Ya}=1 ;$

Tidak $=0 \quad$ Tidak $=0$

\#A.2.2 Jumlah Ekuitas Dana Lancar = Jumlah Aset Lancar - Jumlah Kewajiban

$\mathrm{Ya}=1 ; \quad \mathrm{Ya}=1 ;$

Jangka Pendek

Tidak $=0 \quad$ Tidak $=0$

\#A.2.3 Jumlah Ekuitas Dana Investasi $=$ Jml. Investasi Jangka Panjang + Jml. Aset $Y a=1 ; \quad Y a=1$;

Tetap + Jml. Aset Lainnya - Jml. Kewajiban Jangka Panjang

Tidak $=0$ Tidak $=0$

\#A.2.4 Jumlah Ekuitas Dana Cadangan = Jumlah Dana Cadangan

$\mathrm{Ya}=1 ; \quad \mathrm{Ya}=1 ;$

Tidak $=0$ Tidak $=0$

\#A.2.5 Jumlah Kas = SILPA + Saldo Utang PFK + Pendapatan Ditangguhkan

$\mathrm{Ya}=1 ; \quad \mathrm{Ya}=1 ;$

Tidak $=0 \quad$ Tidak $=0$

\#A.2.6 Investasi Jangka Pendek = Cadangan Investasi Jangka Pendek

$\mathrm{Ya}=1 ; \quad \mathrm{Ya}=1 ;$

Tidak $=0 \quad$ Tidak $=0$

\#A.2.7 Piutang = Cadangan Piutang

$\mathrm{Ya}=1 ; \quad \mathrm{Ya}=1$;

Tidak $=0 \quad$ Tidak $=0$

\#A.2.8 Persediaan $=$ Cadangan Persediaan

$\mathrm{Ya}=1 ; \quad \mathrm{Ya}=1 ;$

Tidak $=0 \quad$ Tidak $=0$

\#A.2.9 Kewajiban Jangka Pendek - Utang PFK = Dana Disediakan untuk Pembayaran Kewajiban Jangka Pendek

$\mathrm{Ya}=1 ; \quad \mathrm{Ya}=1 ;$

Tidak $=0$ Tidak $=0$

\#A.2.10 Jumlah Investasi Jangka Panjang = Ekuitas Dana Diinvestasikan dalam Investasi Jangka Panjang

$\mathrm{Ya}=1 ; \quad \mathrm{Ya}=1 ;$

Tidak $=0$ Tidak $=0$

\#A.2.11 Jumlah Aset Tetap = Ekuitas Dana Diinvestasikan dalam Aset Tetap

$\mathrm{Ya}=1 ; \quad \mathrm{Ya}=1 ;$

Tidak $=0 \quad$ Tidak $=0$

\#A.2.12 Jumlah Aset Lainnya = Ekuitas Dana Diinvestasikan dalam Aset Lainnya

$\mathrm{Ya}=1 ; \quad \mathrm{Ya}=1 ;$

Tidak $=0$ Tidak $=0$

\#A.2.13 Kewajiban Jangka Panjang = Dana yang Disediakan untuk Pembayaran

$\mathrm{Ya}=1 ; \quad \mathrm{Ya}=1 ;$

Kewajiban Jangka Panjang

Tidak $=0 \quad$ Tidak $=0$

\#A.3 Artikulasi Antarpos di Laporan Arus Kas (LAK)

\#A.3.1 Saldo Akhir Kas di BUD tahun 2013 = Saldo Awal Kas di BUD tahun

$\mathrm{Ya}=1$

$\# \mathrm{~N} / \mathrm{A}$ 2014

Tidak $=0$ 
Firdaus \& Ritonga

\begin{tabular}{|c|c|c|c|}
\hline & Uraian & 2014 & 2013 \\
\hline \#A.3.2 & $\begin{array}{l}\text { Kas Bersih dari Aktivitas Operasi = Arus kas masuk akt. operasi - Arus kas } \\
\text { keluar akt. Operasi }\end{array}$ & $\begin{array}{l}\text { Ya }=1 \\
\text { Tidak }=0\end{array}$ & $\begin{array}{l}\text { Ya }=1 \\
\text { Tidak }=0\end{array}$ \\
\hline \#A.3.3 & $\begin{array}{l}\text { Kas Bersih dari Aktivitas investasi aset nonkeuangan = Arus kas masuk akt. } \\
\text { investasi aset nonkeuangan - Arus kas keluar akt. investasi aset } \\
\text { nonkeuangan }\end{array}$ & $\begin{array}{l}\text { Ya }=1 \\
\text { Tidak }=0\end{array}$ & $\begin{array}{l}\text { Ya }=1 \\
\text { Tidak }=0\end{array}$ \\
\hline \#A.3.4 & $\begin{array}{l}\text { Kas Bersih dari Aktivitas pembiayaan = Arus kas masuk akt. pembiayaan - } \\
\text { Arus kas keluar akt. Pembiayaan }\end{array}$ & $\begin{array}{l}\text { Ya }=1 \\
\text { Tidak }=0\end{array}$ & $\begin{array}{l}\text { Ya }=1 ; \\
\text { Tidak }=0\end{array}$ \\
\hline \#A.3.5 & $\begin{array}{l}\text { Kas Bersih dari Aktivitas non anggaran = Arus kas masuk akt. non } \\
\text { anggaran - Arus kas keluar akt. non anggaran }\end{array}$ & $\begin{array}{l}\text { Ya }=1 \\
\text { Tidak }=0\end{array}$ & $\begin{array}{l}\text { Ya }=1 \\
\text { Tidak }=0\end{array}$ \\
\hline \#A.3.6 & $\begin{array}{l}\text { Kenaikan/Penurunan Kas selama periode = Penjumlahan kas bersih dari } \\
\text { setiap aktivitas }\end{array}$ & $\begin{array}{l}\text { Ya }=1 \\
\text { Tidak }=0\end{array}$ & $\begin{array}{l}\text { Ya }=1 \\
\text { Tidak }=0\end{array}$ \\
\hline
\end{tabular}

Penilaian artikulasi dilakukan dengan membandingkan fakta dalam lembar muka LKPD dengan kriteria seperti pada tabel di atas. Kondisi artikulasi setiap kriteria terjadi saat fakta dalam LKPD sesuai dengan kriteria. Fakta yang sesuai kriteria diberi skor 1 dan yang tidak sesuai diberi skor 0 . Setelah keseluruhan kriteria diberikan skor, perolehan skor dijumlahkan secara keseluruhan kemudian dibagi dengan jumlah keseluruhan kriteria dikalikan 100\%. Tingkat capaian artikulasi antarpos LKPD diperoleh dalam bentuk persentase (\%) untuk informasi keuangan tahun 2014 dan 2013.
Berdasarkan kriteria artikulasi antarpos LKPD berbasis kas menuju akrual pada tabel 6, diperoleh hasil analisis sebagai berikut (Tabel 7).

Tabel 7 menunjukkan tingkat capaian artikulasi antarpos LKPD berbasis kas menuju akrual untuk informasi keuangan tahun 2014 dan 2013 dari 61 LKPD yang dianalisis.

Setelah penilaian artikulasi antarpos LKPD, analisis dilanjutkan pada analisis artikulasi antarkomponen LKPD kas menuju akrual dengan kriteria sebagai berikut pada Tabel 8.

Tabel 7

Hasil Analisis Artikulasi Antarpos LKPD Berbasis Kas Menuju Akrual

\begin{tabular}{|c|c|c|c|c|c|c|c|c|c|c|c|}
\hline \multirow{3}{*}{$\begin{array}{l}\text { Artikulasi } \\
\text { Antarpos }\end{array}$} & \multirow{3}{*}{ Thn } & \multicolumn{10}{|c|}{ Kelompok Tingkat Capaian Artikulasi LKPD } \\
\hline & & \multicolumn{2}{|c|}{$100 \%$} & \multicolumn{2}{|c|}{$75 \%$ s.d. $<100 \%$} & \multicolumn{2}{|c|}{$50 \%$ s.d. $<75 \%$} & \multicolumn{2}{|c|}{$25 \%$ s.d. $<50 \%$} & \multicolumn{2}{|c|}{$0 \%$ s.d. $<25 \%$} \\
\hline & & Jml. & $\%$ & Jml. & $\%$ & Jml. & $\%$ & Jml. & $\%$ & Jml. & $\%$ \\
\hline \multirow[t]{2}{*}{ LRA } & 2014 & 61 & 100,00 & 0 & 0,00 & 0 & 0,00 & 0 & 0,00 & 0 & 0,00 \\
\hline & 2013 & 61 & 100,00 & 0 & 0,00 & 0 & 0,00 & 0 & 0,00 & 0 & 0,00 \\
\hline \multirow[t]{2}{*}{ Neraca } & 2014 & 53 & 86,89 & 7 & 11,48 & 1 & 1,64 & 0 & 0,00 & 0 & 0,00 \\
\hline & 2013 & 49 & 80,33 & 12 & 19,67 & 0 & 0,00 & 0 & 0,00 & 0 & 0,00 \\
\hline \multirow[t]{2}{*}{ LAK } & 2014 & 58 & 95,08 & 3 & 4,92 & 0 & 0,00 & 0 & 0,00 & 0 & 0,00 \\
\hline & 2013 & 59 & 96,72 & 2 & 3,28 & 0 & 0,00 & 0 & 0,00 & 0 & 0,00 \\
\hline
\end{tabular}


Analisis Artikulasi Laporan Keuangan Pemerintah Daerah

Tabel 8

Kriteria Artikulasi Antarkomponen LKPD Berbasis Kas Menuju Akrual (\#Y)

\begin{tabular}{|c|c|c|c|}
\hline \multicolumn{2}{|r|}{ Uraian } & \multirow[t]{2}{*}{2014} & 2013 \\
\hline \multicolumn{3}{|c|}{ \#B.1 Artikulasi antara LRA dan Neraca } & \\
\hline \#B.1.1 & SILPA di LRA = SILPA di Neraca & $\begin{array}{l}\mathrm{Ya}=1 \\
\text { Tidak }=0\end{array}$ & $\begin{array}{l}\mathrm{Ya}=1 \\
\text { Tidak }=0\end{array}$ \\
\hline \multicolumn{4}{|c|}{ \#B.2 Artikulasi antara LAK dan Neraca } \\
\hline \#B.2.1 & Saldo Akhir Kas di LAK = Kas di Neraca & $\begin{array}{l}\mathrm{Ya}=1 \\
\text { Tidak }=0\end{array}$ & $\begin{array}{l}\mathrm{Ya}=1 \\
\text { Tidak }=0\end{array}$ \\
\hline \multicolumn{4}{|c|}{ \#B.3 Artikulasi antara LRA dan LAK } \\
\hline \#B.3.1 & Saldo Akhir Kas di LAK >= SILPA di LRA & $\begin{array}{l}\text { Ya }=1 \\
\text { Tidak }=0\end{array}$ & $\begin{array}{l}\text { Ya }=1 \\
\text { Tidak }=0\end{array}$ \\
\hline \#B.3.2 & $\begin{array}{l}\text { Jumlah Pendapatan di LRA = Jumlah Arus Masuk Kas dari Aktivitas } \\
\text { Operasi + Jumlah Arus Masuk Kas dari Aktivitas Investasi Aset } \\
\text { Nonkeuangan }\end{array}$ & $\begin{array}{l}\mathrm{Ya}=1 \\
\text { Tidak }=0\end{array}$ & $\begin{array}{l}\mathrm{Ya}=1 \\
\text { Tidak }=0\end{array}$ \\
\hline \#B.3.3 & $\begin{array}{l}\text { Jumlah Penerimaan Pembiayaan - Penggunaan SiLPA = Jumlah Arus } \\
\text { Masuk Kas dari Aktivitas Pembiayaan }\end{array}$ & $\begin{array}{l}\mathrm{Ya}=1 \\
\text { Tidak }=0\end{array}$ & $\begin{array}{l}\text { Ya }=1 \\
\text { Tidak }=0\end{array}$ \\
\hline \#B.3.4 & $\begin{array}{l}\text { Jumlah Belanja }+ \text { Transfer }=\text { Jumlah Arus Keluar Kas dari Aktivitas } \\
\text { Operasi + Investasi Aset Nonkeuangan }\end{array}$ & $\begin{array}{l}\text { Ya }=1 \\
\text { Tidak }=0\end{array}$ & $\begin{array}{l}\text { Ya }=1 \\
\text { Tidak }=0\end{array}$ \\
\hline \#B.3.5 & $\begin{array}{l}\text { Jumlah Pengeluaran Pembiayaan = Jumlah Arus Keluar Kas dari } \\
\text { Aktivitas Pembiayaan }\end{array}$ & $\begin{array}{l}\mathrm{Ya}=1 \\
\text { Tidak }=0\end{array}$ & $\begin{array}{l}\mathrm{Ya}=1 \\
\text { Tidak }=0\end{array}$ \\
\hline \#B.3.6 & $\begin{array}{l}\text { Jumlah Pendapatan di LRA + Jumlah Penerimaan Pembiayaan - } \\
\text { Penggunaan SILPA = Jumlah Arus Masuk Kas dari Aktivitas Operasi } \\
\text { + Jumlah Arus Masuk Kas dari Aktivitas Investasi Non Keuangan + } \\
\text { Jumlah Arus Masuk Kas dari Aktivitas Pembiayaan }\end{array}$ & $\begin{array}{l}\text { Ya }=1 \\
\text { Tidak }=0\end{array}$ & $\begin{array}{l}\mathrm{Ya}=1 \\
\text { Tidak }=0\end{array}$ \\
\hline \#B.3.7 & $\begin{array}{l}\text { Jumlah Belanja }+ \text { Jumlah Transfer }+ \text { Jumlah pengeluaran pembiayaan } \\
=\text { Jumlah Arus Keluar Kas dari Aktivitas Operasi }+ \text { Jumlah Arus } \\
\text { Keluar Kas dari Aktivitas Investasi Non Keuangan }+ \text { Jumlah Arus } \\
\text { Keluar Kas dari Aktivitas Pembiayaan }\end{array}$ & $\begin{array}{l}\mathrm{Ya}=1 \\
\text { Tidak }=0\end{array}$ & $\begin{array}{l}\mathrm{Ya}=1 \\
\text { Tidak }=0\end{array}$ \\
\hline
\end{tabular}

Sama dengan penilaian artikulasi antarpos di atas, kondisi artikulasi antarkomponen LKPD juga dilakukan dengan membandingkan fakta terhadap kriteria artikulasi. Berdasarkan lembar muka LKPD, fakta yang sesuai kriteria diberi skor 1 dan yang tidak sesuai diberi skor 0. Setelah keseluruhan kriteria diberikan skor, perolehan skor dijumlahkan secara keseluruhan kemudian dibagi dengan jumlah keseluruhan kriteria dikalikan 100\%. Tingkat capaian artikulasi antarkomponen LKPD diperoleh dalam bentuk persentase (\%) untuk informasi keuangan tahun 2014 dan 2013.

Berdasarkan kriteria artikulasi antarkomponen LKPD berbasis kas menuju akrual pada tabel 8, diperoleh hasil analisis sebagaimana ditunjukkan pada tabel 9 di bawah: 
Tabel 9

Hasil Analisis Artikulasi Antarkomponen LKPD Berbasis Kas Menuju Akrual

\begin{tabular}{|c|c|c|c|c|c|c|c|c|c|c|c|}
\hline \multirow{3}{*}{$\begin{array}{c}\text { Artikulasi } \\
\text { Antarkomponen } \\
\text { LKPD }\end{array}$} & \multirow{3}{*}{ Tahun } & \multicolumn{10}{|c|}{ Kelompok Tingkat Capaian Artikulasi LKPD } \\
\hline & & \multicolumn{2}{|c|}{$100 \%$} & \multicolumn{2}{|c|}{$\begin{array}{l}75 \% \text { s.d. } \\
<100 \%\end{array}$} & \multicolumn{2}{|c|}{$50 \%$ s.d. $<75 \%$} & \multicolumn{2}{|c|}{$25 \%$ s.d. $<50 \%$} & \multicolumn{2}{|c|}{$0 \%$ s.d. $<25 \%$} \\
\hline & & Jml. & $\%$ & Jml. & $\%$ & Jml. & $\%$ & Jml. & $\%$ & Jml. & $\%$ \\
\hline \multirow[t]{2}{*}{ LRA - Neraca } & 2014 & 57 & 93,44 & 0 & 0,00 & 0 & 0,00 & 0 & 0,00 & 4 & 6,56 \\
\hline & 2013 & 53 & 86,89 & 0 & 0,00 & 0 & 0,00 & 0 & 0,00 & 8 & 13,11 \\
\hline \multirow[t]{2}{*}{ LAK - Neraca } & 2014 & 44 & 72,13 & 0 & 0,00 & 0 & 0,00 & 0 & 0,00 & 17 & 27,87 \\
\hline & 2013 & 46 & 75,41 & 0 & 0,00 & 0 & 0,00 & 0 & 0,00 & 15 & 24,59 \\
\hline \multirow[t]{2}{*}{ LRA - LAK } & 2014 & 23 & 37,70 & 0 & 0,00 & 0 & 0,00 & 36 & 59,02 & 2 & 3,28 \\
\hline & 2013 & 23 & 37,70 & 0 & 0,00 & 1 & 1,64 & 35 & 57,38 & 2 & 3,28 \\
\hline
\end{tabular}

Tabel 9 menunjukkan tingkat capaian artikulasi antarkomponen LKPD berbasis kas menuju akrual atas 61 LKPD yang dianalisis. Selanjutnya perolehan tingkat artikulasi kumulatif LKPD berbasis kas menuju akrual setiap pemerintah daerah diperoleh dengan cara mengakumulasikan tingkat capaian artikulasi antarpos LKPD dan tingkat capaian artikulasi antarkomponen LKPD yang ditunjukkan dengan perolehan nilai rata-rata tingkat artikulasi LKPD.

\section{Analisis Artikulasi LKPD Berbasis Akrual}

Hasil analisis artikulasi LKPD berbasis akrual dari 5 LKPD yang dianalisis menunjukkan bahwa tidak ada satupun LKPD yang memeroleh tingkat capaian artikulasi LKPD $100 \%$. Hasil keseluruhan analisis artikulasi LKPD ditunjukkan pada tabel 10 berikut.
Tabel 10

Hasil Analisis Artikulasi LKPD Berbasis Akrual

\begin{tabular}{llc}
\hline No. & \multicolumn{1}{c}{ Nama Pemda } & $\begin{array}{c}\text { Tingkat Capaian } \\
\text { Artikulasi }(\%)\end{array}$ \\
\hline 1 & Pemko. Tangerang & 81,37 \\
2 & Pemkab. Banyumas & 96,88 \\
3 & Pemkab. Jepara & 74,04 \\
4 & Pemkab. Temanggung & 73,81 \\
5 & Pemkab. Banyuwangi & 88,10 \\
\hline
\end{tabular}

Hasil analisis di atas diperoleh dari analisis artikulasi antarpos dan antarkomponen LKPD. Berikut ini kriteria analisis artikulasi antarpos LKPD berbasis akrual (Tabel 11).

Berdasarkan kriteria artikulasi antarpos LKPD berbasis akrual pada tabel 11, diperoleh hasil analisis sebagai berikut (Tabel 12).

Tabel 11

Kriteria Artikulasi Antarpos LKPD Berbasis Akrual (\#X)

\begin{tabular}{llll}
\hline \multicolumn{1}{c}{ Uraian } & 2014 & \multicolumn{1}{c}{2013} \\
\hline \#C.1 ARTIKULASI ANTARPOS LRA & & \\
\#.C.1.1 & Jumlah Pendapatan LRA - Jumlah Belanja - Jumlah Transfer $=$ & Ya $=1 ;$ & Ya =1; \\
& Surplus/Defisit LRA & Tidak $=0$ & Tidak $=0$ \\
\#.C.1.2 & SiLPA/SiKPA= Surplus/Defisit LRA + Penerimaan Pembiayaan - & Ya $=1 ; \quad$ Ya $=1 ;$ \\
& Pengeluaran Pembiayaan & Tidak $=0$ & Tidak $=0$ \\
\hline
\end{tabular}


Analisis Artikulasi Laporan Keuangan Pemerintah Daerah

\begin{tabular}{|c|c|c|c|}
\hline & Uraian & 2014 & 2013 \\
\hline \multicolumn{4}{|c|}{ \#C.2 ARTIKULASI ANTARPOS DI LPSAL } \\
\hline \#C.2.1 & SAL akhir 2013 = SAL Awal 2014 & $\begin{array}{l}\text { Ya }=1 \\
\text { Tidak }=0\end{array}$ & $\# \mathrm{~N} / \mathrm{A}$ \\
\hline \multicolumn{4}{|c|}{ \#C.3 ARTIKULASI ANTARPOS DI LAK } \\
\hline \#C.3.1 & $\begin{array}{l}\text { Saldo Akhir Kas di BUD tahun 20x0 = Saldo Awal Kas di BUD tahun } \\
\text { 20x1 }\end{array}$ & $\begin{array}{l}\text { Ya }=1 \\
\text { Tidak }=0\end{array}$ & $\begin{array}{l}\text { Ya }=1 \\
\text { Tidak }=0\end{array}$ \\
\hline \#C.3.2 & $\begin{array}{l}\text { Kas Bersih dari Aktivitas Operasi = Arus kas masuk akt. operasi - Arus } \\
\text { kas keluar akt. Operasi }\end{array}$ & $\begin{array}{l}\text { Ya }=1 \\
\text { Tidak }=0\end{array}$ & $\begin{array}{l}\mathrm{Ya}=1 \\
\text { Tidak }=0\end{array}$ \\
\hline \#C.3.3 & $\begin{array}{l}\text { Kas Bersih dari Aktivitas investasi = Arus kas masuk akt. investasi - Arus } \\
\text { kas keluar akt. investasi }\end{array}$ & $\begin{array}{l}\text { Ya }=1 \\
\text { Tidak }=0\end{array}$ & $\begin{array}{l}\text { Ya }=1 \\
\text { Tidak }=0\end{array}$ \\
\hline \#C.3.4 & $\begin{array}{l}\text { Kas Bersih dari Aktivitas pendanaan }=\text { Arus kas masuk Aktivitas } \\
\text { Pendanaan - Arus kas keluar Aktivitas Pendanaan }\end{array}$ & $\begin{array}{l}\text { Ya }=1 \\
\text { Tidak }=0\end{array}$ & $\begin{array}{l}\text { Ya }=1 \\
\text { Tidak }=0\end{array}$ \\
\hline \#C.3.5 & $\begin{array}{l}\text { Kas Bersih dari Aktivitas Transitoris = Arus kas masuk akt. transitoris - } \\
\text { Arus kas keluar akt. Transitoris }\end{array}$ & $\begin{array}{l}\text { Ya }=1 \\
\text { Tidak }=0\end{array}$ & $\begin{array}{l}\mathrm{Ya}=1 \\
\text { Tidak }=0\end{array}$ \\
\hline \#C.3.6 & $\begin{array}{l}\text { Kenaikan/Penurunan Kas selama periode = Penjumlahan kas bersih } \\
\text { dari setiap aktivitas }\end{array}$ & $\begin{array}{l}\mathrm{Ya}=1 \\
\text { Tidak }=0\end{array}$ & $\begin{array}{l}\mathrm{Ya}=1 \\
\text { Tidak }=0\end{array}$ \\
\hline \multicolumn{4}{|c|}{ \#C.4 ARTIKULASI ANTARPOS LO } \\
\hline \#C.4.1 & $\begin{array}{l}\text { Jumlah Pendapatan LO - Jumlah Beban = Surplus } / \text { Defisit Kegiatan } \\
\text { Operasional }\end{array}$ & $\begin{array}{l}\mathrm{Ya}=1 \\
\text { Tidak }=0\end{array}$ & $\begin{array}{l}\text { Ya }=1 \\
\text { Tidak }=0\end{array}$ \\
\hline \#C.4.2 & $\begin{array}{l}\text { Surplus/Defisit dari Kegiatan Operasional + Surplus/Defisit dari } \\
\text { Kegiatan Non Operasional + Pos Luar Biasa = Surplus } / \text { Defisit-LO }\end{array}$ & $\begin{array}{l}\mathrm{Ya}=1 \\
\text { Tidak }=0\end{array}$ & $\begin{array}{l}\mathrm{Ya}=1 \\
\text { Tidak }=0\end{array}$ \\
\hline \multicolumn{4}{|c|}{ \#C.5 ARTIKULASI ANTARPOS LPE } \\
\hline \#C.5.1 & Ekuitas akhir 2013 = Ekuitas Awal 2014 & $\begin{array}{l}\mathrm{Ya}=1 \\
\text { Tidak }=0\end{array}$ & $\# \mathrm{~N} / \mathrm{A}$ \\
\hline \multicolumn{4}{|c|}{ \#C.6 ARTIKULASI ANTARPOS NERACA } \\
\hline \#C.6.1 & Jumlah Aset $=$ Jumlah Kewajiban + Jumlah Ekuitas & $\begin{array}{l}\text { Ya }=1 \\
\text { Tidak }=0\end{array}$ & $\begin{array}{l}\text { Ya }=1 \\
\text { Tidak }=0\end{array}$ \\
\hline
\end{tabular}

Tabel 12

Tingkat Capaian Artikulasi Antarpos LKPD Berbasis Akrual

\begin{tabular}{lcccccccccc}
\hline \multirow{2}{*}{$\begin{array}{l}\text { Artikulasi } \\
\text { Antarpos }\end{array}$} & \multicolumn{2}{c}{$\begin{array}{c}\text { Pemko. } \\
\text { Tangerang }\end{array}$} & \multicolumn{2}{c}{$\begin{array}{c}\text { Pemkab. } \\
\text { Banyumas }\end{array}$} & \multicolumn{2}{c}{$\begin{array}{c}\text { Jemkab. } \\
\text { Jepara }\end{array}$} & \multicolumn{2}{c}{$\begin{array}{c}\text { Pemkab. } \\
\text { Temanggung }\end{array}$} & \multicolumn{2}{c}{$\begin{array}{c}\text { Pemkab. } \\
\text { Banyuwangi }\end{array}$} \\
\cline { 2 - 12 } & 2014 & 2013 & 2014 & 2013 & 2014 & 2013 & 2014 & 2013 & 2014 & 2013 \\
\hline LRA & 100,00 & 100,00 & 100,00 & 100,00 & 100,00 & 100,00 & 100,00 & 100,00 & 100,00 & 100,00 \\
LPSAL & 100,00 & n.a & 100,00 & n.a & 100,00 & n.a & 100,00 & n.a & 0,00 & n.a \\
LAK & 100,00 & 100,00 & 100,00 & 100,00 & 100,00 & 100,00 & 100,00 & 100,00 & 100,00 & 100,00 \\
LO & 100,00 & 100,00 & 100,00 & 100,00 & 100,00 & 100,00 & 100,00 & 100,00 & 100,00 & 100,00 \\
LPE & 100,00 & n.a & 100,00 & n.a & 100,00 & n.a & 100,00 & n.a & 100,00 & n.a \\
Neraca & 100,00 & 100,00 & 100,00 & 100,00 & 100,00 & 100,00 & 100,00 & 100,00 & 100,00 & 100,00 \\
\hline
\end{tabular}


Tabel 12 menunjukkan tingkat capaian artikulasi antarpos LKPD berbasis akrual untuk informasi keuangan tahun 2014 dan 2013 dari 5 LKPD yang dianalisis.
Setelah penilaian artikulasi antarpos LKPD berbasis akrual, analisis dilanjutkan pada analisis artikulasi antarkomponen LKPD berbasis akrual dengan kriteria sebagai berikut (Tabel 13).

Tabel 13

Kriteria Artikulasi Antarkomponen LKPD Berbasis Akrual (\#Y)

\begin{tabular}{|c|c|c|c|}
\hline & Uraian & 2014 & 2013 \\
\hline \multicolumn{4}{|c|}{ \#D.1 ARTIKULASI ANTARA LRA DAN LPSAL } \\
\hline \#D.1.1 & $\begin{array}{l}\text { Penggunaan SILPA di LRA = Penggunaan SAL sebagai Penerimaan } \\
\text { Pembiayaan Tahun Berjalan di LPSAL }\end{array}$ & $\begin{array}{l}\text { Ya }=1 \\
\text { Tidak }=0\end{array}$ & $\begin{array}{l}\text { Ya }=1 \\
\text { Tidak }=0\end{array}$ \\
\hline \#D.1.2 & SILPA/SIKPA di LRA = SILPA/SIKPA di LPSAL & $\begin{array}{l}\text { Ya }=1 \\
\text { Tidak }=0\end{array}$ & $\begin{array}{l}\text { Ya }=1 ; \\
\text { Tidak }=0\end{array}$ \\
\hline \multicolumn{4}{|c|}{ \#D.2 ARTIKULASI LRA DAN LAK } \\
\hline \#D.2.1 & Kas di LAK >= SILPA di LRA & $\begin{array}{l}\text { Ya }=1 \\
\text { Tidak }=0\end{array}$ & $\begin{array}{l}\text { Ya }=1 \\
\text { Tidak }=0\end{array}$ \\
\hline \#D.2.2 & $\begin{array}{l}\text { Jumlah Pendapatan di LRA = Jumlah Arus Masuk Kas dari Aktivitas } \\
\text { Operasi + Jumlah Arus Masuk Kas dari Aktivitas Investasi - Hasil } \\
\text { Penjuala Kekayaan Daerah yang Dipisahkan - Pencairan Dana } \\
\text { Cadangan }\end{array}$ & $\begin{array}{l}\mathrm{Ya}=1 ; \\
\text { Tidak }=0\end{array}$ & $\begin{array}{l}\mathrm{Ya}=1 ; \\
\text { Tidak }=0\end{array}$ \\
\hline \#D.2.3 & $\begin{array}{l}\text { Jumlah Penerimaan Pembiayaan - Penggunaan SILPA - Pencairan } \\
\text { Dana Cadangan - Hasil Penjualan Kekayaan Daerah yang Dipisahkan } \\
\text { = Jumlah Arus Masuk Kas dari Aktivitas Pendanaan }\end{array}$ & $\begin{array}{l}\mathrm{Ya}=1 ; \\
\text { Tidak }=0\end{array}$ & $\begin{array}{l}\mathrm{Ya}=1 ; \\
\text { Tidak }=0\end{array}$ \\
\hline \#D.2.4 & $\begin{array}{l}\text { Jumlah Belanja dan Transfer = Jumlah Arus Keluar Kas dari Aktivitas } \\
\text { Operasi + Jumlah Arus Keluar Kas dari Aktivitas Investasi - } \\
\text { Pembentukan Dana Cadangan - Penyertaan Modal Pemerintah }\end{array}$ & $\begin{array}{l}\mathrm{Ya}=1 ; \\
\text { Tidak }=0\end{array}$ & $\begin{array}{l}\mathrm{Ya}=1 ; \\
\text { Tidak }=0\end{array}$ \\
\hline \#D.2.5 & $\begin{array}{l}\text { Jumlah Pengeluaran Pembiayaan - Pembentuka Dana Cadangan - } \\
\text { Penyertaan Modal Pemerintah = Jumlah Arus Keluar Kas dari } \\
\text { Aktivitas Pendanaan }\end{array}$ & $\begin{array}{l}\mathrm{Ya}=1 ; \\
\text { Tidak }=0\end{array}$ & $\begin{array}{l}\mathrm{Ya}=1 ; \\
\text { Tidak }=0\end{array}$ \\
\hline \#D.2.6 & $\begin{array}{l}\text { Jumlah Pendapatan di LRA + Jumlah Penerimaan Pembiayaan - } \\
\text { Penggunaan SILPA = Jumlah Arus Masuk Kas dari Aktivitas Operasi } \\
\text { + Jumlah Arus Masuk Kas dari Aktivitas Investasi + Jumlah Arus } \\
\text { Masuk Kas dari Aktivitas Pendanaan }\end{array}$ & $\begin{array}{l}\mathrm{Ya}=1 ; \\
\text { Tidak }=0\end{array}$ & $\begin{array}{l}\mathrm{Ya}=1 ; \\
\text { Tidak }=0\end{array}$ \\
\hline \#D.2.7 & $\begin{array}{l}\text { Jumlah Belanja + Jumlah Transfer + Jumlah pengeluaran pembiayaan } \\
=\text { Jumlah Arus Keluar Kas dari Aktivitas Operasi + Jumlah Arus } \\
\text { Keluar Kas dari Aktivitas Investasi + Jumlah Arus Keluar Kas dari } \\
\text { Aktivitas Pendanaan }\end{array}$ & $\begin{array}{l}\mathrm{Ya}=1 ; \\
\text { Tidak }=0\end{array}$ & $\begin{array}{l}\mathrm{Ya}=1 ; \\
\text { Tidak }=0\end{array}$ \\
\hline \multicolumn{4}{|c|}{ \#D.3 ARTIKULASI ANTARA LAK DAN NERACA } \\
\hline \#D.3.1 & Saldo Kas Akhir di LAK = Saldo Kas di Neraca & $\begin{array}{l}\text { Ya }=1 \\
\text { Tidak }=0\end{array}$ & $\begin{array}{l}\text { Ya }=1 ; \\
\text { Tidak }=0\end{array}$ \\
\hline \multicolumn{4}{|c|}{ \#D.4 ARTIKULASI ANTARA LAK DAN LPSAL } \\
\hline \#D.4.1 & Saldo Kas Akhir di LAK >= LP SAL & $\begin{array}{l}\text { Ya }=1 \\
\text { Tidak }=0\end{array}$ & $\begin{array}{l}\text { Ya }=1 ; \\
\text { Tidak }=0\end{array}$ \\
\hline
\end{tabular}


Analisis Artikulasi Laporan Keuangan Pemerintah Daerah

\begin{tabular}{|c|c|c|c|}
\hline & Uraian & 2014 & 2013 \\
\hline \multicolumn{4}{|c|}{ \#D.5 ARTIKULASI ANTARA LO DAN LPE } \\
\hline \#D.5.1 & Surplus/Defisit - LO di LO = Surplus/Defisit LO di LPE & $\begin{array}{l}\text { Ya }=1 \\
\text { Tidak }=0\end{array}$ & $\begin{array}{l}\text { Ya }=1 \\
\text { Tidak }=0\end{array}$ \\
\hline \multicolumn{4}{|c|}{ \#D.6 ARTIKULASI ANTARA LO DAN NERACA } \\
\hline \#D.6.1 & $\begin{array}{l}\text { Beban Penyusutan di LO = Beban Penyusutan Aset Tetap + Beban } \\
\text { Penyusutan Aset Lain-lain di CaLK }\end{array}$ & $\begin{array}{l}\text { Ya }=1 \\
\text { Tidak }=0\end{array}$ & $\begin{array}{l}\mathrm{Ya}=1 \\
\text { Tidak }=0\end{array}$ \\
\hline \#D.6.2 & $\begin{array}{l}\text { Akumulasi Penyusutan Aset Tetap Tahun } 2013 \text { + Penyusutan Aset } \\
\text { Tetap karena perubahan kebijakan + Penyusutan Aset Tetap } 2014 \text { - } \\
\text { Akumulasi Penyusutan Aset Tetap yang Dihapuskan = Akumulasi } \\
\text { Penyusutan Aset Tetap Tahun } 2014\end{array}$ & $\begin{array}{l}\mathrm{Ya}=1 ; \\
\text { Tidak }=0\end{array}$ & $\begin{array}{l}\mathrm{Ya}=1 ; \\
\text { Tidak }=0\end{array}$ \\
\hline \#D.6.3 & $\begin{array}{l}\text { Akumulasi Penyusutan Aset Lain-lain Tahun } 2013 \text { + Penyusutan } \\
\text { Aset Lain-lain karena perubahan kebijakan + Penyusutan Aset Lain- } \\
\text { lain } 2014 \text { - Akumulasi Penyusutan Aset Lain-lain yang Dihapuskan = } \\
\text { Akumulasi Penyusutan Aset Lain-lain Tahun } 2014\end{array}$ & $\begin{array}{l}\mathrm{Ya}=1 ; \\
\text { Tidak }=0\end{array}$ & $\begin{array}{l}\mathrm{Ya}=1 ; \\
\text { Tidak }=0\end{array}$ \\
\hline \#D.6.4 & $\begin{array}{l}\text { Saldo Penyisihan Piutang Tak Tertagih 20x1 di Neraca }=\text { Penyisihan } \\
\text { Piutang Tak Tertagih 20x0 di Neraca }+ \text { Beban Penyisihan Piutang } \\
\text { Tak Tertagih 20x1 di LO }\end{array}$ & $\begin{array}{l}\mathrm{Ya}=1 ; \\
\text { Tidak }=0\end{array}$ & $\begin{array}{l}\mathrm{Ya}=1 ; \\
\text { Tidak }=0\end{array}$ \\
\hline \multicolumn{4}{|c|}{ \#D.7 ARTIKULASI ANTARA LPE DAN NERACA } \\
\hline \#D.7.1 & Ekuitas Akhir di LPE = Ekuitas di Neraca & $\begin{array}{l}\text { Ya }=1 \\
\text { Tidak }=0\end{array}$ & $\begin{array}{l}\mathrm{Ya}=1 \\
\text { Tidak }=0\end{array}$ \\
\hline
\end{tabular}

Berdasarkan kriteria artikulasi antarkomponen LKPD berbasis akrual pada tabel 13, diperoleh hasil analisis sebagai berikut seperti pada Tabel 14.

Tabel 14 menyatakan bahwa tidak ada satupun LKPD yang memenuhi kriteria 100\% artikulasi antarkomponen LKPD berbasis akrual. Capaian tertinggi diperoleh oleh LKPD Pemkab Banyumas dengan tingkat capaian artikulasi sebesar $93,75 \%$ sedangkan capaian tingkat artikulasi terendah diperoleh oleh Pemkab Jepara sebesar 48,08\%.

Tabel 14

Tingkat Capaian Artikulasi Antarkomponen LKPD Berbasis Akrual

\begin{tabular}{lrrrrrrrrrr}
\hline \multirow{2}{*}{$\begin{array}{l}\text { Artikulasi Antar- } \\
\text { komponen }\end{array}$} & \multicolumn{2}{c}{$\begin{array}{c}\text { Pemko. } \\
\text { Tangerang }\end{array}$} & \multicolumn{2}{c}{\begin{tabular}{c} 
Pemkab. \\
\cline { 2 - 11 }
\end{tabular}} & 2014 & 2013 & 2014 & 2013 & 2014 & \multicolumn{2}{c}{$\begin{array}{c}\text { Pemkab. } \\
\text { Jepara }\end{array}$} & \multicolumn{2}{c}{$\begin{array}{c}\text { Pemkab. } \\
\text { Temanggung }\end{array}$} & \multicolumn{2}{c}{$\begin{array}{c}\text { Pemkab. } \\
\text { Banyuwangi }\end{array}$} \\
\hline LRA - LPSAL & 00,00 & 100,00 & 100,00 & 100,00 & 50,00 & 0,00 & 100,00 & 100,00 & 100,00 & 100,00 \\
LRA - LAK & 42,86 & 42,86 & 85,71 & 100,00 & 28,57 & 28,57 & 14,29 & 14,29 & 42,86 & 28,57 \\
LAK - Neraca & 100,00 & 100,00 & 100,00 & 100,00 & 100,00 & 100,00 & 100,00 & 0,00 & 100,00 & 100,00 \\
LAK - LPSAL & 100,00 & 100,00 & 100,00 & 100,00 & 100,00 & 100,00 & 100,00 & 100,00 & 100,00 & 100,00 \\
LO - LPE & 100,00 & 100,00 & 100,00 & 100,00 & 100,00 & 100,00 & 100,00 & 100,00 & 100,00 & 100,00 \\
LO - Neraca & 25,00 & 100,00 & 75,00 & 100,00 & 50,00 & 100,00 & 75,00 & 100,00 & 50,00 & 100,00 \\
LPE - Neraca & 100,00 & 100,00 & 100,00 & 100,00 & 100,00 & 100,00 & 100,00 & 100,00 & 100,00 & 100,00 \\
\hline
\end{tabular}


Selanjutnya guna memeroleh tingkat artikulasi kumulatif LKPD berbasis akrual setiap pemerintah daerah, diperoleh dengan cara mengakumulasikan tingkat capaian artikulasi antarpos LKPD dan tingkat capaian artikulasi antarkomponen LKPD yang ditunjukkan dengan perolehan nilai rata-rata tingkat artikulasi LKPD berbasis akrual sebagai berikut Tabel 15.

\section{Identifikasi Jenis/Tipe Ketidakartikulasian}

Identifikasi jenis/tipe ketidakartikulasian suatu LKPD yang tidak mencapai tingkat artikulasi $100 \%$ dilakukan melalui penggalian informasi dari data sekunder guna menjawab pertanyaan penelitian dan tujuan penelitian ke2.

Jenis/Tipe Ketidakartikulasian pada LKPD Berbasis Kas Menuju Akrual
Berdasarkan hasil analisis artikulasi LKPD berbasis kas menuju akrual dan hasil mensarikan dari kertas kerja analisis artikulasi LKPD, peneliti mengelompokkan jenis/tipe ketidakartikulasian ke dalam 12 (dua belas) tipe ketidakartikulasian sebagaimana tersaji pada Tabel 16.

Tabel 16 tersebut menunjukkan bahwa ketidakartikulasian antara LRA dan LAK terjadi karena perbedaan perlakuan konsolidasi pada LRA dan LAK menempati kejadian tertinggi sebanyak 37 kejadian atau 38,14\% dari 97 kejadian yang diidentifikasi. LRA dan LAK seharusnya berartikulasi mengingat keduanya berbasis kas dimana semua transaksi kas yang memengaruhi LRA akan sama terlaporkan dalam LAK. Ketidakartikulasian terjadi karena LRA badan layanan umum daerah (BLUD) dikonsolidasikan ke dalam LRA pemerintah daerah sedangkan LAK BLUD tidak dikonsolidasikan ke dalam LAK pemerintah daerah.

Tabel 15

Tingkat Capaian Artikulasi LKPD Berbasis Akrual per Pemda

\begin{tabular}{|c|c|c|c|c|c|}
\hline \multirow[b]{2}{*}{ No. } & \multirow[b]{2}{*}{ LKPD Pemda } & \multirow[b]{2}{*}{ Tahun } & \multicolumn{3}{|c|}{ Capaian Kumulatif } \\
\hline & & & $\begin{array}{c}\text { Instrumen } \\
\# \mathrm{X}\end{array}$ & $\begin{array}{c}\text { Instrumen } \\
\# Y\end{array}$ & $\begin{array}{l}\text { \#X dan \#Y } \\
\text { Per Pemda }\end{array}$ \\
\hline \multirow{2}{*}{1} & \multirow{2}{*}{ Pemko. Tangerang } & 2014 & 100 & 58,82 & \multirow{2}{*}{82,56} \\
\hline & & 2013 & 100 & 71,43 & \\
\hline \multirow{2}{*}{2} & \multirow{2}{*}{ Pemkab. Banyumas } & 2014 & 100 & 88,24 & \multirow{2}{*}{97,06} \\
\hline & & 2013 & 100 & 100 & \\
\hline \multirow{2}{*}{3} & \multirow{2}{*}{ Pemkab. Jepara } & 2014 & 100 & 52,94 & \multirow{2}{*}{75,74} \\
\hline & & 2013 & 100 & 50 & \\
\hline \multirow{2}{*}{4} & \multirow{2}{*}{ Pemkab. Temanggung } & 2014 & 100 & 58,82 & \multirow{2}{*}{77,21} \\
\hline & & 2013 & 100 & 50 & \\
\hline \multirow{2}{*}{5} & \multirow{2}{*}{ Pemkab. Banyuwangi } & 2014 & 93,33 & 64,71 & \multirow{2}{*}{80,58} \\
\hline & & 2013 & 100 & 64,29 & \\
\hline
\end{tabular}


Tabel 16

Tipe Ketidakartikulasian LKPD Berbasis Kas Menuju Akrual

\begin{tabular}{|c|c|c|c|}
\hline \multirow{2}{*}{ No. } & \multirow{2}{*}{ Uraian Tipe Ketidakartikulasian } & \multicolumn{2}{|c|}{ Kejadian } \\
\hline & & Jml. & $\%$ \\
\hline 1 & $\begin{array}{l}\text { Ketidakartikulasian antara LRA dan LAK karena perbedaan perlakuan konsolidasi } \\
\text { pada LRA dan LAK }\end{array}$ & 37 & 38,14 \\
\hline 2 & Perbedaan saldo akhir kas di LAK dan kas di neraca & 18 & 18,56 \\
\hline 3 & Perbedaan SILPA di LRA dan SILPA di neraca & 9 & 9,28 \\
\hline 4 & $\begin{array}{l}\text { Perbedaan jumlah pengeluaran pembiayaan dengan arus kas keluar dari aktivitas } \\
\text { pembiayaan }\end{array}$ & 3 & 3,09 \\
\hline 5 & $\begin{array}{l}\text { Tidak sesuainya dana disediakan untuk pembayaran kewajiban jangka pendek } \\
\text { dengan kondisi kewajiban jangka pendeknya. }\end{array}$ & 7 & 7,22 \\
\hline 6 & Kesalahan klerikal berupa salah mencantumkan angka dengan tepat pada LKPD. & 2 & 2,06 \\
\hline 7 & Saldo kas lebih kecil dari SILPA & 5 & 5,15 \\
\hline 8 & $\begin{array}{l}\text { Saldo kas tidak merefleksikan SILPA, utang PFK dan pendapatan yang } \\
\text { ditangguhkan. }\end{array}$ & 7 & 7,22 \\
\hline 9 & $\begin{array}{l}\text { Jumlah penerimaan pembiayaan selain penggunaan SILPA tidak sama dengan arus } \\
\text { masuk kas dari aktivitas pembiayaan }\end{array}$ & 5 & 5,15 \\
\hline 10 & Kesalahan dalam LAK & 1 & 1,03 \\
\hline 11 & $\begin{array}{l}\text { Saldo awal kas di BUD tahun } 2014 \text { berbeda dengan saldo akhir kas di BUD tahun } \\
2013\end{array}$ & 2 & 2,06 \\
\hline 12 & Kesalahan klasifikasi & 1 & 1,03 \\
\hline & Jumlah Kejadian & 97 & 100,00 \\
\hline
\end{tabular}

\section{Jenis/Tipe Ketidakartikulasian pada}

\section{LKPD Berbasis Akrual}

Berdasarkan hasil analisis artikulasi LKPD berbasis akrual dan hasil mensarikan dari kertas kerja analisis artikulasi LKPD, peneliti mengelompokkan jenis/tipe ketidakartikulasian ke dalam 10 tipe ketidakartikulasian sebagaimana Tabel 17 berikut di bawah.

Tabel 17 tersebut menunjukkan tipe ketidakartikulasian terbanyak terdapat pada empat tipe yang terjadi pada empat LKPD yaitu ketidakartikulasian antara LRA dan LAK karena perbedaan perlakuan konsolidasi pada LRA dan LAK, beban penyusutan, beban amortisasi dan beban penyisihan di LO tidak terrefleksikan dalam neraca.

\section{Kesimpulan, Implikasi, dan Saran}

Simpulan

Penelitian ini bertujuan untuk menganalisis artikulasi LKPD tahun 2014 se-Jawa dan Bali yang beropini WTP serta mengidentifikasi tipe ketidakartikulasian apabila ditemukan LKPD tidak berartikulasi. Analisis artikulasi terbagi atas LKPD berbasis kas menuju akrual sebanyak 61 LKPD dan LKPD berbasis akrual sebanyak 5 LKPD. Setiap LKPD dianalisis pada artikulasi antarpos dan antarkomponen LKPD yang ditunjukkan oleh tingkat capaian artikulasi dalam bentuk persentase. 
Firdaus \& Ritonga

Tabel 17

Tipe Ketidakartikulasian LKPD Berbasis Akrual

\begin{tabular}{|c|c|c|c|}
\hline \multirow{2}{*}{ No } & \multirow{2}{*}{ Uraian Tipe Ketidakartikulasian } & \multicolumn{2}{|c|}{ Kejadian } \\
\hline & & Jumlah & $\%$ \\
\hline 1 & $\begin{array}{l}\text { Jumlah pengeluaran pembiayaan selain pembentukan dana cadangan dan } \\
\text { penyertaan modal di LRA tidak terefleksikan dalam arus kas keluar dari aktivitas } \\
\text { pendanaan di LAK }\end{array}$ & 3 & 12,50 \\
\hline 2 & SAL akhir tahun 2013 berbeda dengan SAL awal tahun 2014 & 1 & 4,17 \\
\hline 3 & $\begin{array}{l}\text { Ketidakartikulasian antara LRA dan LAK karena perbedaan perlakuan konsolidasi } \\
\text { pada LRA dan LAK }\end{array}$ & 4 & 16,67 \\
\hline 4 & $\begin{array}{l}\text { Selisih akumulasi penyusutan aset tetap tahun } 2014 \text { dengan tahun } 2013 \text { di neraca } \\
\text { tidak terrefleksikan dalam beban penyusutan aset tetap di LO dan pengurangan } \\
\text { akumulasi penyusutan akibat penghapusan aset tetap }\end{array}$ & 4 & 16,67 \\
\hline 5 & $\begin{array}{l}\text { Selisih amortisasi aset tidak berwujud tahun } 2014 \text { dengan tahun } 2013 \text { di neraca } \\
\text { tidak terwujud dalam beban amortisasi di LO }\end{array}$ & 4 & 16,67 \\
\hline 6 & $\begin{array}{l}\text { Selisih penyisihan piutang tahun } 2014 \text { dengan tahun } 2013 \text { di neraca tidak } \\
\text { terwujud dalam beban penyisihan piutang di LO }\end{array}$ & 4 & 16,67 \\
\hline 7 & $\begin{array}{l}\text { selisih Penggunaan SILPA di LRA dengan penggunaan SAL sebagai penerimaan } \\
\text { pembiayaan tahun berjalan di LPSAL }\end{array}$ & 1 & 4,17 \\
\hline 8 & Kesalahan pencantuman SILPA di LRA dengan SILPA di LPSAL. & 1 & 4,17 \\
\hline 9 & $\begin{array}{l}\text { Selisih penerimaan pembiayaan selain penggunaan SILPA, pencairan dana } \\
\text { cadangan dan hasil penjualan kekayaan daerah yang dipisahkan di LRA dengan } \\
\text { arus masuk dari aktivitas pendanaan di LAK, }\end{array}$ & 1 & 4,17 \\
\hline 10 & $\begin{array}{l}\text { Saldo akhir kas di LAK berbeda dengan kas dan setara kas di neraca pada laporan } \\
\text { keuangan tahun } 2013 .\end{array}$ & 1 & 4,17 \\
\hline & Jumlah Kejadian & 24 & 100,00 \\
\hline
\end{tabular}

Hasil analisis memberikan bukti empiris bahwa tidak semua LKPD yang beropini WTP telah berartikulasi 100\%. Pada LKPD berbasis kas menuju akrual sebanyak 7 LKPD dari 61 LKPD yang dianalisis atau 11,48\% memeroleh tingkat capaian artikulasi 100\%, sedangkan sisanya sebanyak 54 LKPD tidak mencapai tigkat artikulasi 100\%. Pada LKPD berbasis akrual tidak ada satupun dari 5 LKPD yang dianalisis yang memeroleh tingkat capaian artikulasi $100 \%$.

Hasil analisis juga memberikan identifikasi tipe ketidakartikulasian pada LKPD yang tidak mencapai tingkat artikulasi 100\%. Pada LKPD berbasis kas menuju akrual dapat diidentifikasi sebanyak 12 tipe ketidakartikulasian dengan 97 kejadian. Pada LKPD berbasis akrual dapat diidentifikasi 10 tipe ketidakartikulasian dengan 24 kejadian.

\section{Implikasi}

Implikasi yang diperoleh dari penelitian ini ialah:

1) Kualitas LKPD tahun 2014 tidak sepenuhnya memenuhi kriteria andal karena dari 66 LKPD yang diteliti, hanya 7 LKPD yang mencapai tingkat artikulasi 100\%, sedangkan LKPD yang tidak mencapai tingkat artikulasi 100\%, keandalan LKPD menjadi berkurang.

2) LKPD audited dan beropini WTP seharusnya merupakan opini tertinggi yang mampu menjadi jaminan keandalan suatu LKPD karena telah melalui audit yang independen 
(Jusup, 2010, h. 45). Namun, hasil penelitian ini mengindikasikan adanya kelemahan dalam pelaksanaan reviu oleh inspektorat maupun pelaksanaan pemeriksaan oleh auditor eksternal, khususnya terkait penilaian artikulasi.

\section{Saran}

Berdasarkan simpulan hasil penelitian di atas, disarankan kepada:

1) penyusun LKPD dan konsultan pendamping semestinya melakukan penyusunan dan penyajian sesuai dengan SAP, memanfaatkan teknologi informasi untuk menghindari kesalahan klerikal dan human error, dan melakukan penilaian artikulasi LKPD secara mandiri sebelum LKPD diserahkan kepada inspektorat daerah,

2) Inspektorat daerah semestinya melakukan reviu LKPD dengan seksama sesuai dengan pedoman reviu dan melakukan analisis artikulasi secara mendalam sebelum menerbitkan laporan hasil reviu LKPD,

3) BPK RI semestinya dapat mempertimbangkan untuk memasukan analisis artikulasi LKPD pada program pemeriksaan untuk melihat secara menyeluruh LKPD yang akan diperiksa, dan melakukan koreksi yang diperlukan setelah dilakukan pendalaman apabila ditemukan LKPD tidak berartikulasi,

4) penyusun SAP dan Kemendagri agar menyusun pedoman penyusunan LKPD guna menjawab perbedaan persepsi khususnya saat penyusunan laporan konsolidasian jika suatu pemerintah daerah memiliki entitas akuntansi/entitas pelaporan berupa BLUD.

\section{Keterbatasan Penelitian dan Saran} Penelitian Selanjutnya

Penelitian ini memiliki keterbatasan sebagai berikut:

1) Sumber data identifikasi tipe ketidakartikulasian berasal dari penggalian informasi yang berasal dari data sekunder. Sangat disarankan agar penelitian selanjutnya melengkapi dengan menggunakan dengan melakukan wawancara mendalam kepada pihak-pihak terkait.

2) Penelitian ini tidak mendeskripsikan faktorfaktor yang menyebabkan LKPD tidak berartikulasi, peneliti hanya menggali dan menjelaskan tipe-tipe ketidakartikulasian pada suatu LKPD yang tidak berartikulasi. Penelitian artikulasi LKPD selanjutnya dapat menggali faktor-faktor penyebab LKPD berbasis akrual yang tidak berartikulasi melalui pendekatan kualitatif dan pendalamannya menggunakan data primer dan sekunder.

\section{Daftar Pustaka}

Badan Pemeriksa Keuangan Republik Indonesia, 2015, Ikbtisar Hasil Pemeriksaan Semester II BPK RI Tabun 2014, Jakarta.

Badan Pemeriksa Keuangan Republik Indonesia, 2015. Ikbtisar Hasil Pemeriksaan Semester I BPK RI Tabun 2015, Jakarta.

Bahnson, P.R., Miller, P.B.W. \& Budge, B.P., 1996, Nonarticulation in Cash Flow Statements and Implications for Education, Research and Practice', Accounting Horizons 10(4), 1-15.

Creswell, J.W., 2014, Research design: Qualitative, quantitative, and mixed methods approach 4th edition, Sage Publications, California. 
Givens, H.R., 1966, 'Basic Accounting Postulates', The Accounting Review 41(3), 458-463.

Jusup, A.H., 2010, Auditing (Pengauditan), Bagian Penerbitan STIE YKPN, Yogyakarta.

Kinnunen, J. \& Koskella, M., 1999, 'Do cash flows reported by firms articulate with their income statements and balance sheets? Descriptive evidence from Finland', The European Accounting Review $8(4)$.

Mahmudi, 2007, Analisis laporan keuangan pemerintah daerab: Panduan bagi eksekutif, DPRD, dan masyarakat dalam pengambilan keputusan ekonomi, sosial, dan politik, UPP STIM YKPN, Yogyakarta.

Pusat Bahasa Departemen Pendidikan Nasional Republik Indonesia, 2008, Kamus Besar Bahasa Indonesia daring, Jakarta.

Ratmono, D. \& Sholihin, M., 2015, Akuntansi keuangan daerah berbasis akrual, UPP STIM YKPN, Yogyakarta.

Republik Indonesia, 1945, Undang-Undang Dasar Negara Republik Indonesia Tabun 1945 Amandemen IV, Jakarta.

Republik Indonesia, 2003. Undang-Undang Nomor 17 Tabun 2003 tentang Keuangan Negara, Jakarta.

Ritonga, I.T., 2010, Reviu laporan keuangan pemerintab daerah, LKMPD, Yogyakarta.

Soewadji, Y., 2012, Pengantar metodologi penelitian, Mitra Wacana Media, Jakarta.

Sugiyono., 2015, Metode penelitian kuantitatif, kualitatif dan $R$ $\sigma^{\circ} D$, Alfabeta, Bandung.

Suwardjono., 2013, Teori akuntansi: Perekayasaan pelaporan keuangan Ed 3, BPFE, Yogyakarta.

Weygandt, J.J., Kimmel, P.D. \& Kieso, D.E., 2013, Financial Accounting IFRS 2nd Edition, John Wiley \& Sons, New York. 